E3S Web of Conferences 2, 03005 (2014)

DOI: $10.1051 /$ e3sconf/ 20140203005

(C) Owned by the authors, published by EDP Sciences, 2014

\title{
Rural Development. Challenges and opportunities for Europe
}

\author{
Agata Spaziante
}

Dipartimento Interateneo Territorio, Politecnico di Torino

\section{Introduction}

In our plundered planet where the primary resources are taking the risk of very serious damages and crisis, there is one resource on which the concern of scholars, politicians, technicians, even in an increasing sensibility to the sustainability of development, is less focused then oil, gas, water etc.: it's soil.

It must be stressed that this resource is scarce and strategic not less than the more considered ones (water, air, energy, etc.), because the life of 6 billion of human beings today (and 7 billion on 2050) will depend on the soil availability for food production. It will not be easy to produce food enough to feed a so big amount of people; the possibility to pursue such elementary aim depends on the quantity, quality and correct use of soil and particularly on the availability of soil suitable to agriculture, i.e. the rural soil. This is the reason way the price of food is continuously growing and in future it will grow much more quickly. It's not a chance that China (and not only) is buying a huge of rural areas in Africa, as a strategy to prevent profiteering on the food price and to be sure they will have food enough for the big amount of population they will have in future. And we must think that next wars will be probably raised by conflicts around good agricultural soil availability. It must be stressed, anyway, that in the last years the concern to protect and enhance this resource is increasing, particularly in European Community

At the same time urbanisation and changing urban-rural linkages are the most significant process of land use change in Europe. The increase in urbanisation fosters a spread of built-up areas and extension of transport networks. The changing nature of the relationship between rural and urban land uses has deep consequences both for human quality of life and for the environment.

In the near-urban landscape the establishment of recreational facilities such as theme parks and golf courses and the conversion of farmsteads into residences and hobby farms are also very visible markers of the urbanisation trend.

Only through an appropriate governance of land use and urban development and a complete rethinking of the settlement pattern and urbanization process, we could ensure the responsible use of this primary and unplayable resource, essential for the future economic development. This is true for the entire planet and for Europe as well, but even more for Italy where this primary resource is strategic, as its quantity is relatively scarce and its quality is very high, in contrast to what happens for other primary resources (oil, gas, precious metals, etc...) almost totally absent in our Country. As a matter of fact this resource in 2011 has enabled our Country to produce agricultural products for 40 billion euro, 30 of which exported. The right use of this resource could contribute to the re-starting of the economy that at the moment is, on the contrary, in a worrying stand-by situation. Finally I emphasize that "feeding the planet; energy for life" is the subject of the next Expo 2015 that is located in Italy (Milan) and can be considered a demonstration of the relevance of agriculture for the planet survival and of the top position of Italy on the topic. 
It must be stressed anyway that safeguarding and developing rural areas ${ }^{1}$, is aimed not only to support food production but to ensure another fundamental function: the protection and improvement of environmental quality of the planet. This is the meaning of the so called "multifunctional" use of rural development and this is the reason of considering rural areas deeply involved into the most relevant challenges and most promising opportunities for the environmental policies.

What this paper aims to propose as a contribution to the discussion on the relationship between science and the future, 40 years after the publication of the Report on "The Limits to Growth", is a reflection on what Europe is doing, with light and shade, to correct the perverse processes of transformation that are reducing the amount and even more the quality of the soil resource. I would submit to discussion what EU Commission is carrying on with an only partial success; in order contrast the risks not only for food production but for the environmental quality as well.

Moreover in the paper two items will be discussed:

- the role that the techniques and in particular those involved in the processes of governance of urban and country planning (i.e. technical disciplines such as urban planning and environmental and territorial planning, less usually considered when discussing the problems of controlling the quality of human life on the planet in the next centuries ) must play in order to protect both the soil resource and the rural environment;

- the responsibilities and the available tools that affect the promoters of economic but social and environmental policies as well, about actions able to safeguard primary resource soil. A main actor as "European Union" (and particularly European Commission) is here considered, as it's supposed to drive the Member States towards virtuous actions by using both the leverage of relevant funds (the Structural Funds) and the constraints of mandatory directives about the strategic matters falling in the supranational competences, as the environment is.

In thinking about the changes that are involving the planet and the threats to the primary resources which the future of our species and our society depends on, we cannot avoid to analyze, expose and understand what is happening, but we must much more be involved, as technicians, in trying to develop and test tools suitable to carry on the best actions able to contrast the risks of wasting this primary resource (the soil) and of damage the climate conditions. The responsibility to develop tools such as plans, programs, evaluation methods etc. and not only analytical studies is a mandatory commitment for the technical, political, administrative actors which have to implement policies.

Both analyzing and planning are the particular concern of urban and regional planners whose aim is to drive the governance of territories towards right collective interest; and at the moment the first and right collective interest ought to be the contrast to the risks of wasting primary resources and contributing to the climate change worsening.

This is the reason why the paper will examine the problem of the relationship between science and future by the side of the urban and regional planners and on the special topic of the rural soil primary resource management, in order to drive the territorial change towards a sustainable development.

\section{Why a new settlement paradigm is necessary?}

The critical waste of the primary resource soil in Europe, is mainly due to the current paradigm of population and activities settlement, strongly dominated since XIX century by a "metropolisation" process: the city is the place where the majority of people want to live, where migrant's flows are directed to, where each new inhabitant would like to find a home, a job, a better life than they had in their place of origin.

The cities today house $50 \%$ of the world population and use $75 \%$ of the resources of the whole planet: and these percentages are continuously growing. Over $70 \%$ of Europe's population is now living in urban areas, and these in turn have grown by almost $80 \%$ over the last fifty years.

\footnotetext{
${ }^{1}$ Rural areas include not only agricultural areas but areas covered by forests, parks, lawns, protected natural zones as well.
} 
This paradigm is the reference model for the contemporary society, in developed countries. It should be pointed out that the process is continuously accelerating; since 1950, in Europe an area as large as northern Italy has been urbanized and only in the decade between 1990 and 2000 over 800 thousand hectares of land (more than three times the size of Luxembourg) have been subtracted to non-urban uses ${ }^{2}$.

In Italy, the land consumption produced by this process of urbanization in the decades prior to 1990 was already carried out at a rate of $0.6 \%$ per year (i.e. from 100.000 to 150.000 hectares per year or 400 acres per day), but in the last period, 1990-2005, the urbanization process affected 244.202 hectares / year, with a further acceleration in the last period till 2008, when the urban sprawl was growing $4.1 \%$ per year.

Therefore, urbanization increased by $500 \%$ from 1956 to 2001 . These figures mean that every citizen is attributed an average of 230 my of urban land; more than 100 municipalities have urbanized in 50 years more than $50 \%$ of their extension; only $14 \%$ of the Italian territory is far more than 5 miles from an urban centre ( and only $28 \%$ is far more than $3.5 \mathrm{~km}$ ). These figures give the idea of the "urban continuum" affecting the Italian territory, particularly in the plain of Northern Italy where we can speak of a "Po valley metropolis". This process was a great opportunity for the economic progress of Italian economic and social mobility along the 50 years after the II World War.

And a similar process happened in Europe, where relevant results in terms of growth of the economic well-being of the population could be got during the XX century, but a very high environmental cost was paid. (Ferlaino, 2009) ${ }^{4}$

Many papers in this Conference stressed that cities are responsible for a serious problem of environmental sustainability, the solution of which is considered the biggest challenge we face today and in the near future together with the need to ensure conditions of life (and of an acceptable quality of life) to the urban population. As a consequence the urbanization process contributes to both the reduction of the primary resource soil and to the environmental degradation: a double attack on the primary resource's availability for the future generations.

This trend of soil waste, continuously going on until five years ago, could not be justified in Italy by a real housing problem: from 1980 there is a good documentary evidence that divergence between population size (stable or decreasing) and land urbanization (continuously growing) was growing. So the building expansion was due to the diffusion of a wrong settlement pattern much more than to a lack of housing: the aim of living in a house on property produced an artificial demand for housing so that while in the 70 ies $30,6 \%$ of population was living in households, today over $80 \%$ of the population lives in a house on property and only $17.7 \%$ lives in a rented house. This settlement model pushed housing demand (more than 2 millions of households were built between 2000 and 2007) and as a consequence city expansion and urban sprawl increased, even in absence of population growth.

The waste of rural soil was worsened by the related diffusion of large commercial structures (malls, outlets, supermarkets, etc.) and large mobility infrastructures (airports, railway stations, motorways, etc.), subtracting soil for agriculture and fragmenting the extra-urban territory.

While the urban sprawl was continuing to subtract soil to the agriculture, a reverse process of empting areas inside the city was going on since three decades: the crisis of the productive sector spreading all over the industrialized world since the "70ies (and exploding in Italy during the 80ies) increased the amount of vacant land and Brownfield's inside and around the cities, in the areas where the industrialization of XIX and XX centuries settled firms and plants. As a consequence during the

\footnotetext{
${ }^{2}$ European Commission, Joint Research Centre, European Soil Portal, http://eusoils.jrc.ec.europa.eu/.

${ }^{3}$ Cassatella C., Spaziante A., Murano C, Carbone M., Consumo di suolo, consumo di paesaggio? Prospettive di ricerca sulla misura delle ricadute dei Programmi di Sviluppo Rurale, in "Valutazione Ambientale”, n. 16, pp. 12-18, 2009.

${ }^{4}$ Ferlaino F., Consumo di suolo e attività di piano in Carta del territorio. La proposta del Piemonte per un nuovo governo del territorio regionale", IRES Piemonte, Torino 2009, pp. 63-68.
} 
90 ies the possibility of re-cycling industrial vacant land promoted in many cities the strategy of regenerating the economy and the urban quality of these territories proposing new relevant opportunities to the private speculative investments. The Brownfield's requalification pushed the reusing of buildings and areas in order to offer the real estate market new "empty" areas inside the very compact cities of our Country (as well as in the majority of the "developed" Countries) to build housing settlements, offices, commercial districts where there were industrial plants. It must be emphasized that while the private activities were widely expanded, no many opportunities were picked up to improve quantity and quality of public facilities and public space: the private city, in general, has expanded much more than the public city

So the paradox of the current settlement paradigm went on for decades: while rural areas were waterproofed, subtracted to agriculture and occupied by buildings, urban areas inside the city were abandoned and left empty or partially re-built for new urban uses.

A new situation must be registered since 2008: the continuation of the industrial crisis; the decommissioning of urban facilities such as barracks, abattoirs, mental hospitals, etc.; the real estate market crisis are adding new empty buildings and areas inside the cities; but the economic bad previsions and the credit crunch are completely compromising the perspective of their re-use; moreover, the quantity of new houses, offices, retail activities not sold and not used are improving, so worsening the real estate market functioning and leaving many urbanized areas out of any use but no more useful as a soil resource for food production or environmental quality improvement.

Moreover it must be emphasized that the big economical crisis that is still involving all the developed Countries, exploded around the " housing bubble "(i.e. the over production of houses) and may be considered the extreme evolution of the current urbanization model, the maximum expression of the contradictions characterizing the settlement paradigm dominating the "developed" Countries and Italy more than other cases. It's necessary, therefore, to overcome this terrible crisis absorbing the enormous fallout produced by the abnormal building production promoted during the last decades, by the irresponsible financing of real estate market but overall changing the settlement paradigm that artificially boosted the dream of being a home owner anyway, so expanding the cities infinitely. And a possible positive result of the crisis is just the failing of the current model: in 2013 only $29 \%$ of the families would use their savings by investments in house building, while only seven years before $70 \%$ of the families would have invested in "bricks".

In summary, this long and wide inconsistent process of wasting the primary resource "soil" is one of the paradoxes connected to the settlement paradigm dominating our socio-economic system that we have to fight in order to correct the perverse trend of our transformation process. And this is probably the right moment to promote a complete trend reversal of the urbanization model, driving the change towards more virtuous aims.

Moreover we must emphasize that, in the same time, the awareness of the risks of the planet and the commitment of the States in this direction have grown up; after the Conference in Rio de Janeiro of 1992 the most accountable institutions and many public and private actors subscribed or promoted declarations, standards, guidelines promising actions in contrast to the environmental condition decline, including the contrast to the urban settlement pattern that was recognized as the responsible of the soil waste and one of the factors negatively affecting the planet environmental quality.

It's a pity, anyway, that not many of these promises were really carried on and that the current critical situation of the economy all over the developed Countries is still more reducing the engagement of the States and Regions on this virtuous policy. Neither this deluding disengagement of the main actors can be considered surprising: we cannot forget that even during more favorable economic periods national institutions being responsible of the territorial governance in the most developed Countries were not able, in many cases, to get innovative tools of land government, such as new acts adapted to the environmental new problems and able to consider the soil as a primary resource to be saved and respected. The additional costs and the contrast of economic strong powers fought often against urban models more respectful of the environmental problems. And in the last five years these conflicting interests are contrasting more and more the environmental aims in the territorial change, due to the socio-economic general crisis: so a better settlement pattern could be more easily imposed by one side (the stop of the building sector as a consequence of the population 
economic crisis) but less easily by the other side (the contrast of the strong powers to the environmental aims privilege).

This general resistance to adapt the land governance to the new environmental needs, emphasized by both the climate negative change and the new knowledge about the environmental processes, were much more evident in Italy, where the effects of the current settlement model are producing particularly serious negative consequences. Italy is rich in quality of its natural and built environment all over the Country. The need to manage this critical situation of contrasting processes became more and more urgent in the last five years as the economic crisis in Italy is particularly acute and drastic deterioration of the settlement conditions is very worrying.

What is possible to do and what is oriented to do one of the main European actors of the economic and political management in the European Countries (the European Commission) in order to control and correct this dangerous perspective of worsening the use of the primary resource "soil" in the next years?

\section{Common Agricultural Policy (CAP) and Rural Development Programmes (RDP): the European challenge for a more responsible use of the primary resource soil}

It's clear that a better use of this strategic resource, actually threatened by the pressures and changes taking place all over Europe, needs strong actions to ensure that the primary resource soil, as well as the primary resources air and water, are used within the limits of sustainability, so that the next generations can get the availability of the resources necessary to assure both the food production and the environmental quality, now carried to a risky condition.

Only recently, anyway, the concept that what is the best in ecological terms, may be the best in social and economic (agronomic) terms too and may promote a better development, as it may correct the dangerous disequilibrium of the current settlement model and give priority to public goals such as environmental protection, multifunctionality, biodiversity, employment.

The most recent EU Policy Framework and, in particular, the Common Agricultural Policy (CAP) ${ }^{5}$ and its second pillar devoted to Rural Development, stress the importance of agriculture as a driver to support land management and to improve the environmental and the socio economic development of rural areas.

The new concepts supported by the beginning CAP 2014 - 2020 promote even more the multifunctional role of countryside and the new challenges of rural areas for the environmental protection and valorisation: they recognize in the sustainable rural development an important role in facing climate change, water management, bio-energy and biodiversity. Through the new CAP the EU Commission has encouraged Member States to move more funds from production subsidies towards targeted measures which will improve rural landscape and biodiversity and to offer incentives to farmers to make environmental improvements. It' the so called "multifunctionality", which refers to the numerous benefits that agricultural policies may provide for a country or region. Generally speaking, multifunctionality refers to the non-trade benefits of agriculture that is benefits other than commerce and food production. These include - in the World Trade Organisation definition of multifunctionality - environmental protection, landscape preservation, rural employment, and food security. In particular, according to the new CAP, environment and landscape should be the most important public goods provided directly and indirectly by agriculture. An effective slogan to describe

\footnotetext{
${ }^{5}$ The Common Agricultural Policy reflects the more general European Strategy oriented to support cohesion; and cohesion needs to get a harmonic development. This is the main aim of the European Commission action that has a timing controlled by the Structural Funds' Programming period till now was divided into three periods: 2000-06, 2007-13, 2014-20. At the moment the second period is over and the new period (2014 - 2020) is beginning, even if a delay is registered in the complex mechanism of the new program launch.
} 
this transition toward a new model of European agriculture could be "from food to environment and landscape production". Rural landscape, in particular, is a new and important addition to the previous main objectives: due to its multifaceted character, which includes natural, cultural and social values, its relationship with agriculture is extremely complex. There is an increasing recognition that landscape is not only an essential element to be preserved, but also an economic asset which can offer significant opportunities for the territorial and economic development of the territories as a whole and particularly for the peri-urban areas where it could become a factor of territorial development in terms of agriculture income, population growth and employment creation. In the western countries, where the problem of food production for the inhabitants is not an emergency, the role of urban and periurban agriculture in a multifunctional sense (i.e. for water storage, for the maintenance of the periurban landscape, recreation and revitalization of degenerated areas, urban greening, etcetera) is receiving more and more attention.

These are really the new main strategies for the rural sustainable development, diverting funds from production subsidies towards targeted environmental measures which will improve rural landscape and biodiversity, so encouraging Member States and their own Regions to offer incentives to farmers to make environmental improvements ${ }^{6}$.

So all these aims were included in the Rural Development Programs (RDPs) and the EU Rural Development Regulation provides a flexible framework to support sustainable rural development objectives.

For this reason the environmental dimension of sustainability is deeply rooted in the Community strategic guidelines for rural development: the Council decision of 20 February 2006 on Community strategic guidelines for rural development (programming period 2007 to 2013), 2006/144/EC, already explains how agriculture continues to be the largest user of rural land, as well as a key determinant of the quality of the countryside and the environment and show some apprehension towards rural areas, which defines as characterized by a very large diversity of situations, ranging from remote rural areas suffering from depopulation and decline to peri-urban areas under increasing pressure from urban centers. It stresses that in some areas the abandonment of farming could engender serious environmental risks.

In this perspective, the relationship between Rural planning and Territorial Planning, not yet well managed, could change the planning of rural areas but, at the same time, should change the Territorial Planning of these areas.

The new regulation broadens the possibilities to use the Rural Development Programs 2014-2020 to boost growth and create jobs in rural areas - in line with the Lisbon Strategy - and to improve sustainability, in line with the Göteborg sustainability goals, but an effective coordination between Rural and Territorial Planning ought to be ensured: and this is not easy, particularly in Countries where strong speculative pressures dominate the building market and, as a consequence, the Planning process, like in Italy.

In the following two chapter's short information about the cited tools that the EU Commission is promoting since 2000 as a support to change the current model of using the primary resource "soil" is exposed.

\section{The main tool to preserve and value rural land, rural landscape and environment: the Rural Development Programs (RDP)}

\footnotetext{
${ }^{6}$ On 20 November 2008 the EU agriculture ministers reached a political agreement on the so called "Health Check" of the Common Agricultural Policy. Among a range of measures, Ministers also agreed to increase modulation, whereby direct payments to farmers are reduced and the money transferred to the Rural Development Fund. This allows a better response to the new challenges and opportunities faced by European agriculture: it includes climate change, a better water management, the protection of biodiversity, and the production of green energy. The Eu intention is to push Member States to assist dairy farmers in sensitive regions to adjust their local policies to the new market situation.
} 
The 2007-13 Rural Development Programs (RDP) ${ }^{7}$ was just over on 31st December 2013. It may be considered the major tool for achieving economic, social and environmental policy priorities across rural areas. The 27 Member States of the European Union have prepared during the $2006-2007$ their national rural development strategies on the basis of six community strategic guidelines finalized to:

- identify the areas where the use of EU support for rural development creates the most value added at EU level;

- make the link with the main EU priorities (Lisbon, Göteborg);

- ensure consistency with other EU policies, in particular cohesion and environment; accompany the implementation of the new market orientated CAP and the necessary restructuring it will entail in the old and new Member States.

The six strategic guidelines are:

1. improving the competitiveness of the agricultural and forestry sectors;

2. improving the environment and countryside;

3. improving the quality of life in rural areas and encouraging diversification;

4. building local capacity for employment and diversification;

5. translating priorities into programs;

6. promoting complementarity between community instruments.

The Rural Development Regulation sets out the legal framework within which the RDP must operate. The Rural Development policy 2007-2013 focus on three areas in line with the "three axes" of measures laid down in the new rural development regulation:

Axis 1: improving the competitiveness of the agriculture and forestry sectors;

Axis 2: improving the environment and countryside - this will be used primarily;

Axis 3: improving rural quality of life and diversification of the rural economy.

Within these themes 34 "measures" are detailed; these measures set out the activities which have been considered eligible to receive funding. There is also a fourth axis called "Leader Approach" which operates across axes 1, 2 and 3. Each of the Member States and their own Regions have developed and implemented their own RDP based on these three themes, adjusted to the local situations and priorities, with the addition of some specific "measures".

The second "axis", in particular, can be read like an attempt to bring up to date the traditional agricultural politics, through a vocabulary and a set of instruments that declare innovation for logic and approach to territorial dynamics and that pursue, at the same time, the intention to protect the environment. Axis 2 provides measures to protect and enhance natural resources, as well as preserving high nature value farming and forestry systems and cultural landscapes in Europe's rural areas.

The Community strategic guidelines for rural development suggest that the funds devoted to axis 2 must contribute to three EU-level priority areas:

- preservation and development of biodiversity, high nature value farming and forestry systems, traditional agricultural landscapes;

- water quality;

- climate change.

The measures available under axis 2 should be used to integrate these environmental objectives and contribute to the implementation of the agricultural and forestry Natura 2000 network, to the Göteborg commitment to contrast biodiversity decline by 2010, to the objectives laid down in Directive 2000/60/EC of the European Parliament and of the Council of 23 October 2000 establishing a framework for Community action in the field of water policy, and to the Kyoto Protocol targets for climate change mitigation.

\footnotetext{
${ }^{7}$ RDP 2007-2013, like its predecessor acting during the period 2000-06, was funded by the European Agricultural Fund for Rural Development (EAFRD) and is aimed at "improving competitiveness in the agriculture and forestry sector, safeguarding and enhancing the rural environment and fostering competitive and sustainable rural businesses and thriving rural communities".
} 
The EU Rural Development Regulation asks each Member State to submit a National Strategic Plan for Rural Development. In Italy the National Strategic Plan (Piano Strategico Nazionale per lo Sviluppo Rurale) provides the general framework to 21 different Rural Development Programs, developed for each Italian Region; each of them had to be equipped with a Strategic Environmental Assessment (SEA).

\section{The main tool to assess the environmental impacts of plans and programs: the Strategic Environmental Assessment (SEA)}

In order to pursue these objectives, each Member State had (and will have in future as well) to support its own Rural Development Program (RDP) by applying the second tool promoted by the EU Commission in order to safeguard and appraise the environmental quality of any change: this is the Strategic Environmental Assessment (SEA), that the European Directive 2001/42/EC of the European Parliament and Council issued on 2001 in order to assess the effects of plans and programs on the environment just at the beginning of any proposal of change, eventually suggesting modifications and compensations of plans and programs. The objective of the SEA process is to provide for a high level of protection of the environment and to contribute to the integration of environmental considerations into the wide process of territorial change, with a special view to promoting sustainable development.

The SEA was focused at the end of a long and wide technical and political debate about the best way to preserve the environment in a very early step of proposing plans and programs, affecting almost any initiative to change the current dynamics with any environmental relevant implication. It pretends to come just before the more consolidated and diffused Environmental Impact Assessment (EIA) used since 1985 for assessing the environmental impacts of projects but considered as a too limited tool for getting an effective protection of environment as not able to take environmental problems into the decision-making process.

"Environmental Impact Assessment (EIA) is one of the most successful policy innovations of the 20th Century" (Sadler and Verheem, 1996) but about ten years after, according to (Sadler and DalalClayton, 2005) only by a Strategic Environmental Assessment (SEA) of plans and programs it could be possible "to promote and further develop methodologies at policy, strategy and project levels for sustainable development decision-making". The environment is multi-dimensional, holistic, interconnected, dynamic, complex, and uncertain and it requires a multi-disciplinary problem solving, facing the whole social, economical and environmental contents of sustainability. SEA is recognized and promoted as an approach towards sustainability and it's recognized as a tool or, better, a process adapted to the legal and institutional background and planning system of each Country, but devoted to assist and facilitate decision-making. Its goal is to analyze a variety of alternative development scenarios and through public participation discuss and share the cumulative environmental and social impacts of each one of them, in order to get the better choice for both the development and the environment (i.e. a "sustainable development")

SEA origin can be found into the National Environmental Policy Act (1969), which promoted efforts to prevent environmental damage through a systematic interdisciplinary approach to ensure appropriate consideration of presently non-quantified environmental values. A relevant statement of SEA is the requirement for a detailed statement to accompany "proposals for legislation and other major federal actions significantly affecting the (...) environment." Into the EU Directive 2001/42/EC (Art.1), better known as "SEA Directive", SEA is defined as a process orientated "to provide a high level of protection to the environment and to contribute to the integration of environmental considerations into the preparation and adoption of plans and programs with a view to promoting sustainable development". The SEA directive represents an important step into the field of the European environmental law and introduced into the planning process of all the 27 Countries of EU new steps involving an analysis of the environment status, critical problems and probable impacts due to the plan/program; the elaboration of an "Environmental Report" (ER) collecting all the information; public consultations about the plan/program and the ER; the institutional decision's communication, 
where the comments and objections had to be either rejected or accepted, modifying the previous proposal; the public diffusion of the final decisions.

In order to meet the obligations under the SEA Directive 2001/42/EC a consultation process has to accompany the programming and the assessment processes. It has to provide the stakeholders the opportunity to express their opinions on the findings of the Environmental Report. In order to support the consultation and participation process the Environmental Report has to be equipped with a "nontechnical summary". The Environmental Reports and the non-technical summaries of the plan/program have to be published to support non technical actors during the consultation processes and to provide information about the plan/program and on the environmental effects of alternative approaches.

In summary, the SEA process is structured into the following main steps: (see Tab 1)

- collecting and presenting information on the environmental baseline and current problems and the likely future evolution;

- predicting significant environmental effects of the program, including those of strategic alternatives, and providing suggestions for negative impacts' mitigation and compensation;

- contrasting adverse environmental effects through suitable policies and/or mitigation measures;

- consulting the public and authorities with environmental responsibilities as part of the assessment process;

- monitoring the environmental effects of the program during its implementation.

\section{The assessment of the environmental impacts of the Rural Development Program: the SEA of RDP}

The perspective of the EU Commission in making compulsory the SEA for the Programs supported by the Structural Funds is to oblige each Country to incorporate principles of sustainability in the policy and programming process, to discuss alternatives while options were still open, to anticipate the environmental problems and to encourage public authorities towards integration of environment and sustainability issues in decision-making through a controlled and certified technical process of analysis and monitoring of the environment status and evolution, in order to drive the change towards the EU common aims. And this perspective is particularly relevant for the RDP that can have so wide and deep impacts on the availability and quality of primary resource rural soil and, much more, on the environment and climate change affecting so large areas of the European Countries.

Moreover the EU Commission issued a special and detailed Regulation (1698/2005/EC) that gives rules and technical indications in order that Member States shall establish a system of ongoing evaluation for their RDPs, so allowing the continuous control of the RDP implementation and the possibility to modify the program when the ongoing results show that the environmental aims could not be pursued.

According to the Regulation 1698/2005/EC (that details the rules to pursue in the SEA process) and to the Common Monitoring and Evaluation Framework (CMEF) (that standardizes the technical content of the assessment) the SEA must be integrated directly into the ex-ante evaluations of Rural Development Programs. The CMEF provided a framework for monitoring and evaluating all rural development interventions for the programming period 2007-2013, establishing performance, accountability, sustainability of the program. The CMEF establishes how a common set of indicators to be followed by all the 27 Countries so that Rural Development Programs will contribute to pursue EU priorities and aims and provide a comprehensive source of data for mid-term and ex-post evaluation of the 2007-13 programming period. The strategic aim of the SEA for the RDP is to focus preventively on the hypothetical limits, opportunities and alternatives to actions and measures for supporting the rural development by the Structural Fund towards a sustainable agriculture and the reduction of environmental negative impacts, contributing to pursue the EU general aims by the preliminary definition of the criteria and the possible options for a sustainable development of the territory (Partidàrio and Clark, 2000; Fischer and Seaton, 2002). 
The SEA for RDP provides a complex and precise set of technical contents that all the $27 \mathrm{EU}$ Countries have to accomplish and to respect. Compulsory sets of common indicators are listed in the CMVF:

baseline indicators defined at the start of the programming period will allow assessment of the starting situation and form the basis for the development of the program strategy. They fall into two categories:

- Objective related baseline indicators directly linked to the wider objectives of the program and Context related baseline indicators. These provide information on relevant aspects of the general contextual trends that are likely to have an influence on the performance of the program;

- resource or input indicators refer to the budget allocated to each level of the assistance output indicators relate to activity. An output is considered to be everything that is obtained in exchange for public expenditure;

- output indicators measure activities directly realized within programs. These activities are the first step towards realizing the operational objectives of the intervention and are measured in physical or monetary units;

- result indicators relate to the direct and immediate effect brought about by a program.

- impact indicators represent the consequences of the program beyond its direct and immediate interaction with addressees or recipients. Impacts fall within two categories; 'specific impacts' which occur after a certain lapse of time but are directly linked to the action taken, and 'global impacts' that are longer term effects affecting a wider population (see tab. 2).

The Regulation 1698/2005/CE details any step of the process for preparing, assessing, deciding, monitoring the RDP by the support of the SEA, as the tables 1 and 2 show synthetically, referred to the case of Piedmont Region RDP 2007-13.

If, on one side, we can say that SEA concepts and rules have been widely acquired and accepted all over the European Union, on the other side we have to admit that their implementation still represents a great challenge for the Member States and the efficacy of the tool is far from being satisfying, both in a general sense and in the particular case of RPD.

My opinion is based on direct and on-the-field experience in the technical assistance to the Strategic Environmental Assessment (SEA) of the RDP of Piedmont Region (Italy) ${ }^{8}$, that gave me a particularly significant opportunity to verify the potentiality of the SEA as a valuable tool for promoting a more responsible use of the primary resource soil but, at the same time, the strong resistance of both technical and political local authorities in applying correctly this innovative tool for environment early protection. As a matter of fact the risks for the rural environment in this Region are very high: in the Italian Northern regions there is the larger part of the strategic resources of the Country in terms of land and water, together with the most important industrial plants, some of the biggest cities and a very rich and a high quality agriculture. As a consequence, conflicting interests of the main stakeholders are strongly fighting, each actor trying to orient the economy as well as the land planning towards its own convenience, with no consideration of the environmental general effects of the actions.

\section{The main priorities of EU Commission for a sustainable rural development in the next programming period}

Now the ongoing programming period 2007-2013 is over and the European Commission has to propose new and stronger initiatives in order to get better results both in general sense and particularly on the environmental conditions improvement towards 2020.

\footnotetext{
${ }^{8}$ The SEA of the RDP for Piedmont Region was drawn out by a team of the Dipartimento Interateneo Territorio of Politecnico di Torino including Agata Spaziante (coordinator), Mirko Carbone, Chiara Murano, Carlo Rega and it has going on since 2007. The team was involved in the second step of the SEA process, i.e. the "in itinere" SEA, that supported the Mid-term SEA Report, till the end of the year 2010 .
} 
"For the next period 2014 - 2020 the EU Commission is proposing five measurable EU targets that will steer the process and be transferred into national targets: for employment; for research and innovation; for climate change and energy; for education; and for fighting against poverty. They represent the direction we should take and will be used to measure our success". (Juan Manuel Barroso, march 2010)

Three priorities should be the heart of Europe 2020:

- smart growth $=$ developing an economy based on knowledge and innovation.

- sustainable growth = promoting a more resource respectful, greener and more competitive economy.

- inclusive growth $=$ fostering a labor intensive economy, promoting economic, social and territorial cohesion.

These three priorities, mutually reinforcing each other, offer a synthetic vision of Europe's social market economy strategy for the 21st century: there is a large consensus that the EU should commonly agree on a limited number of headline targets for 2020 and these targets should be representative of a smart, sustainable and inclusive growth. They must be measurable, able to reflect the diversity of Member States conditions and based on sufficiently reliable data for the purposes of a comparison between the 27 European Countries, such as the SEA process would foster by the assessment of the RDP effects on the rural environment and on the use of the primary resource soil in the release proposed for the new programming period, at the moment still in definition.

The operational definition of the new tools for pursuing the best use (in both quantity and quality sense) of the soil primary resource during the next period 2014-20 is in a worrying delay. We will verify afterwards which changes will be introduced into RDP, SEA and CMVF in order to improve their capacity to drive really the territorial changes towards a more responsible use of the primary resources and a less dangerous impact of the agriculture on the environment.

At the moment I think interesting for this Conference to stress the 6 "priorities", each of them with a set of operational focus areas (18), that will address the needs of the programming area during the 2014-2020 period towards a wider policy framework, substituting the 4 Axis of the current (2007-13) RDP:

It's hoped that this framework will support the rural development with a more efficient control of the environmental impacts of these very relevant Structural Funds on a so wide part of the European territory.

May we hope that the next 7 years of the rural development in Europe and particularly in Italy will really get a better use of the primary resource rural soil and a reduction of the threats to the environment? Our experience gives not many hopes in this direction.

\begin{tabular}{|c|c|c|c|c|c|}
\hline \multicolumn{6}{|c|}{ European Union priorities for Rural Development 2014-2020 } \\
\hline $\begin{array}{l}\text { Fostering } \\
\text { knowledge } \\
\text { transfer and } \\
\text { innovation in } \\
\text { agriculture, } \\
\text { forestry and } \\
\text { rural }\end{array}$ & $\begin{array}{l}\text { Promoting food } \\
\text { chain } \\
\text { organization } \\
\text { and risk } \\
\text { management in } \\
\text { agriculture }\end{array}$ & $\begin{array}{l}\text { Enhancing } \\
\text { competitiveness } \\
\text { of all types of } \\
\text { agriculture and } \\
\text { farm viability }\end{array}$ & $\begin{array}{l}\text { Restoring, } \\
\text { preserving and } \\
\text { enhancing } \\
\text { ecosystems } \\
\text { dependent on } \\
\text { agriculture and } \\
\text { forestry }\end{array}$ & $\begin{array}{l}\text { Promoting } \\
\text { resource } \\
\text { efficiency and } \\
\text { supporting the } \\
\text { shift towards a } \\
\text { low carbon and } \\
\text { climate } \\
\text { resilient in } \\
\text { agriculture, } \\
\text { food and } \\
\text { forestry sectors }\end{array}$ & $\begin{array}{l}\text { Promoting } \\
\text { social inclusion, } \\
\text { poverty } \\
\text { reduction and } \\
\text { economic } \\
\text { development in } \\
\text { rural areas }\end{array}$ \\
\hline
\end{tabular}




\section{Conclusion. Challenges, opportunities and risks for the rural development}

Summarizing the content of the previous six parts of this paper, I would emphasize, as a conclusion, the following three items:

- against the waste of the soil resource, it's necessary to re-think the current lifestyle and urban model to contrast the social, economical and environmental decline a sense of greater responsibility in the management of resources has to be developed;

- knowledge and technical efficacy in monitoring the development towards sustainability must be implemented;

- against the waste of the soil resource, it's necessary to re-think the current lifestyle and urban model.

It is widely recognized that the economy is in crisis and that this crisis will last for a long time more.

It's well known and equally recognized that cities and territories are in a critical situation as well, as exposed in the par. 2. But we wonder which actions will avoid that cities and territories can worsen their conditions and, much more, which role these components could play in order to contribute, on the contrary, to the recovery of the whole system's environmental quality. This question is being asked since some years, much more in scientific debates and in the reflections of public and private actors than in the political debates. "The crisis is when the old dies and the new is not yet born" said Antonio Gramsci, and this thought is an invitation to get quickly to the search for new ways and new perspectives of changing, because our old development model is dying and a new model is not yet appearing.

I would like to draw the attention of researchers on the reflection that the relevant components of the severe difficulties of our economic systems are certainly deepened by the effects of irresponsible management of territories and cities, but perhaps a much more relevant reason is the delay in rethinking the current lifestyle and urban model, focused on targets that appear today no longer acceptable and no longer sustainable without dramatic consequences for the generations that will follow ours.

To contrast the social, economical and environmental decline a sense of greater responsibility in the management of resources has to be developed

The dramatic worsening of the settlement conditions and the weak capacity to control the territorial change by planning a sustainable development were already affecting the European (and Italian territory much more) before the last economic crisis and were not even stopped by the crisis; on the contrary, they are still going on worsening the economic problems that were affecting our Countries since a longer period.

In particular, in Italy it was well registered the shifting between the economic decline and the decline in the real estate sector: the decline of the economy began at least ten years ago, while the real estate sector, which is responsible of the majority of the urban growth, registered largely positive trends at least until 2008. And we have to emphasize that even in the most favourable economic period, the urban structure and organization of our country were not innovated and were not able to get more modern local institutions and rules that could promote a governance of the system comparable to other European countries, preventing the processes of decline already involving many areas of our territory. Now, under the current conditions of scarce economic resources, it looks to become less probable the return to a sense of greater responsibility in the management of these assets.

The feeling of a less generous future for the next generations compared with the expectations of the current generation is diffusing an effect of disengagement and passive acceptance of a declining and losing destiny. So, although the economic and territorial crisis are due, at least partially, to independent processes, their mutual perverse effects are likely to influence and extend both of them.

It seems therefore right to propose this community of researchers some reflections and suggestions that aim to counteract this trend of stagnation or even recession with proposals that would react to the critical issues driven by a lifestyle and a settlement pattern that contributed so quickly and widely to the deterioration of the territorial, environmental, economic conditions of our Countries. 
To stop the decline and begin to drive towards economical and environmental sustainability of the development it's necessary a resolute change of the cultural approach, bringing back the use of natural resources to virtuous territorial cycles and much more turning urban models and relationships between country and city to sustainable territorial processes, as well.

It is clear that the un-sustainability and the low quality of the environment depend not only by the problem of resources, but also by to wrong use of them and by the lack of strategies or even just ideas to go out of the crisis of the settlements inherited by our prestigious past, reviewing the economic, social, territorial models on which to base a future development, inevitably different not only from the past but from the present as well. A deep sense of responsibility in the management of resources has to be developed by the political actors and a strong competence on the scientific tools for correcting the development processes has to be developed by the technical staffs, in the country and urban planning technical sectors as well.

knowledge and technical efficacy in monitoring the development towards sustainability must be implemented

Although the ongoing experiences of RDP implementation and of SEA application to planning and programming are not encouraging an optimistic perspective for the next European programming period 2014-20, the paper has brought some arguments supporting the thesis that the recent reforms of European rural policy would and could preserve and valorise both the primary resource soil and the rural environment.

Analysing these technical tools (RDP, SEA) with their complex content of rules, steps, indicators etc., the double and integrated programming and assessing processes try to promote an iter marked by some elements which would face the strategic knots of the rural development and the risk of wasting a strategic resource.

Will these tools really get the result to bring the territorial changes towards a more desirable future?

By a better use of the rural soil and the support of the Structural Funds offered to the European Member States' by the Rural Development Programs, it would be possible to diffuse in the rural districts the Eco System Services (ESS) (environmental positive impacts) i.e.:

- biodiversity improvement;

- water cycle regulation;

- hydro-geological risk reduction;

- landscape protection and appreciation;

- local development (typical local productions, tourism, historical architecture, etc.) support.

Europe offers aims, resources, rules, technical tools probably not in the most effective way but oriented to get a sustainable development, by preserving the rural environment without reducing the economic development. RDP+SEA can be considered as effective tools to pursue a sustainable rural development and to assess and monitor the effects of rural policies on environment and landscape for a balanced regional growth.

They stress the importance of environment evolution comprehension, participation promotion, action implementation monitoring and awareness about environmental problems and policies increasing. They are structured in order to involve all the actors up to individual farmers in virtuous policies. This is the only way to get that the rural territory can become a "public good" to preserve for the future generations.

But this aim implies, anyway, that the processes that can drive these changes could be better understood; we need to improve our knowledge and create better tools to assess the future social, environmental and economic impacts of any change on the environment. Only by the improvement of scientific competences we can help politicians to identify effective strategies for the planning of sustainable land use systems.

As a matter of fact the cited tools (RDP, SEA) can be considered a challenge and an opportunity for a better future of life and environment quality; they can be improved, their use can become more effective, the country and urban planning discipline could (and should) develop better competences to support an innovative planning and the best application of each tool. 
Nevertheless, I am obliged to express my doubts about the feasibility of this hypothesis: the past experiences seem to forecast as more probable the trend of a disappointing implementation of these tools, that could go on being used in a non-effective way, so compromising the expectations about their role for a real change in rural planning.

In this case the major challenges and opportunities focused by the EU Commission for contrasting the threats to the primary resources and to the European rural environment would be lost and the perspective of a more sustainable millennium for the rural, as well as for the urban, areas could be cancelled.

But this is the perspective that this Conference and researchers would not consider as acceptable! 


\section{References}

R. Capello, A. Hoffmann, a cura di, Sviluppo urbano e sviluppo rurale tra globalizzazione e sostenibilità, Associazione Italiana di Scienze Regionali, Franco Angeli, Milano (1998).

Clayton, D., \& Sadler, B. (2005). Strategic Environmental Assessment (SEA) of Plans and Programmes, Earthscan, London

Council of Europe (COE). (2000). European Landscape Convention (ELC). Council of Europe, Strasbourg

Davico L.,(2004), Sviluppo Sostenibile. Le dimensioni sociali, Carocci, Roma.

Directorate General for Agriculture and Rural Development. (2001). Handbook on Common Monitoring and Evaluation Framework. Guidance document, pp. 9-10

European Commission (2001) Directive of the European Parliament and the Council on Strategic Environmental Assessment. June 27, 2001

European Commission. (2005). Council Regulation on Support for Rural Development by the European Agricultural Fund for Rural Development (EAFRD) n. 1698/2005

European Environmental Agency (EEA). (2006). Urban Sprawl in Europe - The Ignored Challenge. EEA Report n. 10/2006

Grangetti E. (2006), Analisi delle trasformazioni urbane in Piemonte nel decennio 1991-2001 mediante l'uso di tecniche GIS (Geographic Information System), Master Universitario Europeo del Politecnico di Torino in "Tecniche per la progettazione e la valutazione ambientale", Torino.

Guidicini P. (1986), Il rurale riemergente. Un percorso storico su ipotesi di razionalità nell'agricolo e nella non città, Franco Angeli, Milano.

Hoffmann A.(2006), La Nuova Politica di Sviluppo Rurale, Franco Angeli, Milano.

Ingersoll R. (2004), Sprawltown. Cercando la città in periferia, Meltemi, Roma.

Paolillo P.L., (2002), a cura di, Problematiche del parametro suolo. Uno sguardo preoccupato alla situazione regionale, Franco Angeli, Milano.

Partidàrio M.R., Clark R. (2000), Perspective on Strategic Environmental Assessment, Lewis Publishers, USA.

Sadler B., Verheem (1996), Strategic Environmental Assessment 53: Status, Challenges and Future Directions, Ministry of Housing, Spatial Planning and the Environment, The Netherlands, and the International Study of Effectiveness of Environmental Assessment.

Sadler B., Dalal-Clayton (2005), Strategic Environmental Assessment. A sourcebook and reference guide to international experience, Earthscan, London.

Schmidt M., Joao E., Albrecht E., (2006, II edition), Implementing strategic environmental assessment, Springer

Thérivel R. e Partidario M. R. (1996), The Practice of Strategic Environmental Assessment, Earthscan, London.

Thérivel R., Wilson E., Thompson S., Heaney D., Pritchard D. (1992), Strategic Environmental Assessment, Earthscan, London.

Journal and book articles:

Antrop, M. (2004). Landscape change and the urbanisation process in Europe. Landscape and Urban Planning, 67: 9-26.

Di Iacovo F. (2004), "Welfare rigenerativo e nuove forme di dialogo nel rurbano toscano", Rivista di Economia Agraria, vol IV, pp. 164-185.

Fischer T.B., Seaton K. (2002), Strategic Environmental Assessment: Effective Planning Instrument or Lost Concept?, in Planning Practice and Research, Abingdon e Cambridge (Ma.), 2002, 1, p. 31-44.

Jha-Thakur, U., Gazzola, P., Peel, D., Fischer, T. B., \& Kidd, S. (2009). Effectiveness of strategic environmental assessment - The significance of learning. Impact Assessment and Project Appraisal, Vol. 27, pp. 133-144 
Geist, H.J. et al. (2006), "Causes and Trajectories of Land-Use/Cover Change”, In: E.F. Lambin and H. J. Geist (Editor), Land-Use and Land-Cover Change. Local Processes and Global Impacts, Berlin, Heidelberg, New York,42-70.

Glasson J., Gosling J. (2001), SEA and regional planning - overcoming the institutional constraints: some lessons from the EU, European Environment ${ }^{\circ}$ 11, 2001, 2, p.89-102.

Hersperger, A.M. and Bürgi, M., (2007), "Driving forces of landscape change in the urbanizing limmat valley, Switzerland", In E. Koomen, J. Stillwell, A. Bakema and H.J. Scholten (Editors), Modelling Land-Use Change Progress and application, Dordrecht, The Netherlands.

Lambin, E.F., Geist, H.J. and Lepers, E. (2003), Dynamics of Land-Use and Land-Cover Change in Tropical Regions. Annu. Rev. Environ. Resour., 28: 205.241.

Spaziante A., Murano C. (2009), "Rural Development Programs and Strategic Environmental Assessment: towards a Sustainable Rural Territory" in International Journal of Agricultural Resources, Governance and Ecology, Vol. 8, Ns 2/3/4 pag 205 - 222

Spaziante A., Murano C. (2009), "La VAS nei Psr 2007-2013. Etica ed estetica nella tutela dell'ambiente e del paesaggio", in Moccia F.D., I valori in urbanistica fra etica ed estetica, Roma, Edizioni Scientifiche Italiane, 2009.

Spaziante A., Cassatella C., Murano C., Carbone M. (2009), "Consumo di suolo, consumo di paesaggio? Prospettive di ricerca sulla misura delle ricadute dei Programmi di Sviluppo Rurale", Valutazione Ambientale, n. 16, luglio-dicembre 2009, pp.12-17.

Spaziante A., Murano C. (2008), "La VAS nei Programmi di Sviluppo Rurale: snodi critici del doppio processo di programmazione / valutazione nei PSR 2007 - 2013 delle Regioni Piemonte e Valle d'Aosta", in L. Colombo, S. Losco, C. Pacella (editors) La valutazione ambientale nei piani e nei progetti, Ed. Le Penseur, Brienza (Potenza), maggio 2008, pagg. 291 - 300

Thérivel R., Walsh F. (2006), The Strategic Environmental Assessment Directive in the UK: 1 Year Onwards, Environmental Impact Assessment Review, Vol. 26 pp. 663-675. 
Table 1. The SEA process of the Piedmont Rural Development Program 2007/2013: the main steps

\begin{tabular}{|c|c|c|c|}
\hline \multirow{2}{*}{ Programming process } & \multicolumn{2}{|c|}{ Strategic Environmental Assessment process } & \multirow{2}{*}{ Chrono-programme } \\
\hline & Elaboration & $\begin{array}{c}\text { Consultation and } \\
\text { participation process }\end{array}$ & \\
\hline $\begin{array}{c}\text { Phase 1: } \\
\text { preliminary steps }\end{array}$ & $\begin{array}{l}\text { Elaboration and approval of } \\
\text { the Regional Strategic } \\
\text { Document (regional } \\
\text { framework for the RDP) }\end{array}$ & & May 2005 /May 2006 \\
\hline $\begin{array}{l}\text { Phase 2: } \\
\text { definition of the } \\
\text { objectives and of the } \\
\text { main actions of the } \\
\text { RDP }\end{array}$ & $\begin{array}{c}\text { Elaboration of the structure } \\
\text { of the preliminary assessment } \\
\text { report. } \\
\text { Choice of the environmental } \\
\text { components to be considered } \\
\text { into the Environmental Report } \\
\text { (biodiversity, water, soil, } \\
\text { landscape...) }\end{array}$ & $\begin{array}{c}\text { Activation of the environment } \\
\text { technical group. } \\
\text { Definition of the } \\
\text { Environmental Authorities } \\
\text { Consultation of the } \\
\text { Environmental Authorities }\end{array}$ & May /October 2006 \\
\hline $\begin{array}{l}\text { Phase 3: } \\
\text { elaboration of the } \\
\text { RDP }\end{array}$ & $\begin{array}{l}\text { Elaboration of the } \\
\text { Environmental Report }\end{array}$ & $\begin{array}{l}\text { Meetings with the } \\
\text { programming structures }\end{array}$ & $\begin{array}{l}\text { October 2006/ } \\
\text { Febbruary } 2007\end{array}$ \\
\hline $\begin{array}{l}\text { Phase 4: } \\
\text { public introduction of } \\
\text { the RDP }\end{array}$ & $\begin{array}{l}\text { Elaboration of the non- } \\
\text { technical summary }\end{array}$ & $\begin{array}{l}\text { Consultation of the } \\
\text { Environmental Authorities, of } \\
\text { the environmental } \\
\text { association, of the } \\
\text { stakeholders and of the public }\end{array}$ & December 2006 \\
\hline $\begin{array}{l}\text { Phase 5: } \\
\text { integration of the } \\
\text { results of the } \\
\text { consultation process } \\
\text { into the Programme }\end{array}$ & $\begin{array}{l}\text { Analysis of the opinion and of } \\
\text { the different position of the } \\
\text { stakeholders. } \\
\text { Adjustments and Integrations } \\
\text { at the RDP. }\end{array}$ & & $\begin{array}{c}\text { Jennuary/Febbruary } \\
2007\end{array}$ \\
\hline $\begin{array}{c}\text { Phase 6: } \\
\text { adoption of the RDP } \\
\text { by the responsible } \\
\text { Authority }\end{array}$ & $\begin{array}{l}\text { Synthesis declaration of the } \\
\text { RDP responsible Authority }\end{array}$ & $\begin{array}{l}\text { Information of the } \\
\text { Environmental Authorities } \\
\text { and publication. }\end{array}$ & Mars 2007 \\
\hline $\begin{array}{c}\text { Phase 7: } \\
\text { negotiation with the } \\
\text { EC and final approval } \\
\text { of the RDP }\end{array}$ & $\begin{array}{l}\text { Construction of the } \\
\text { monitoring system }\end{array}$ & & June - October 2007 \\
\hline $\begin{array}{l}\text { Phase 8: } \\
\text { implementation of the } \\
\text { RDP }\end{array}$ & & & $2008-2013$ \\
\hline $\begin{array}{c}\text { Phase 9: } \\
\text { Monitoring of RDP } \\
\text { SEA in itinere. }\end{array}$ & $\begin{array}{c}\text { Elaboration of the } \\
\text { Environmental Mid Term } \\
\text { Report }\end{array}$ & & December 2010 \\
\hline $\begin{array}{c}\text { Phase } 10 \\
\text { Conclusion of the RDP }\end{array}$ & & & $31^{\text {st }}$ December 2013 \\
\hline
\end{tabular}


Table 2. RDP of Piemonte RDP SEA 2007/13. The value proposed as aim for the Evironmental Impact indicators measuring the results of the implementation at the end of the period

\begin{tabular}{|c|c|c|}
\hline \multicolumn{2}{|c|}{ Indicators } & Value referred to Piemonte RDP \\
\hline 4 & $\begin{array}{c}\text { Farmland Bird Index (as measurement of trend reversal in } \\
\text { biodiversity decline) }\end{array}$ & $+5-10 \%$ \\
\hline 5 & $\begin{array}{c}\text { High natural value farmland and forestry areas (as } \\
\text { improvement in the quantity of high natural value areas) }\end{array}$ & $+3 \%$ \\
\hline 6 & $\begin{array}{c}\text { Change in gross nutrient balance (as reduction of N and P } \\
\text { presence in the water) }\end{array}$ & $\begin{array}{c}\text { GNB: }-13 \% \mathrm{~kg} \mathrm{~N} / \mathrm{ha} \\
\text { GPB: }-30 \% \mathrm{~kg} \mathrm{P} / \mathrm{ha}\end{array}$ \\
\hline 7 & $\begin{array}{c}\text { Alternative energy production (as contribution to reduce the } \\
\text { climate change) }\end{array}$ & $+12 \mathrm{Ktoe}$ \\
\hline
\end{tabular}
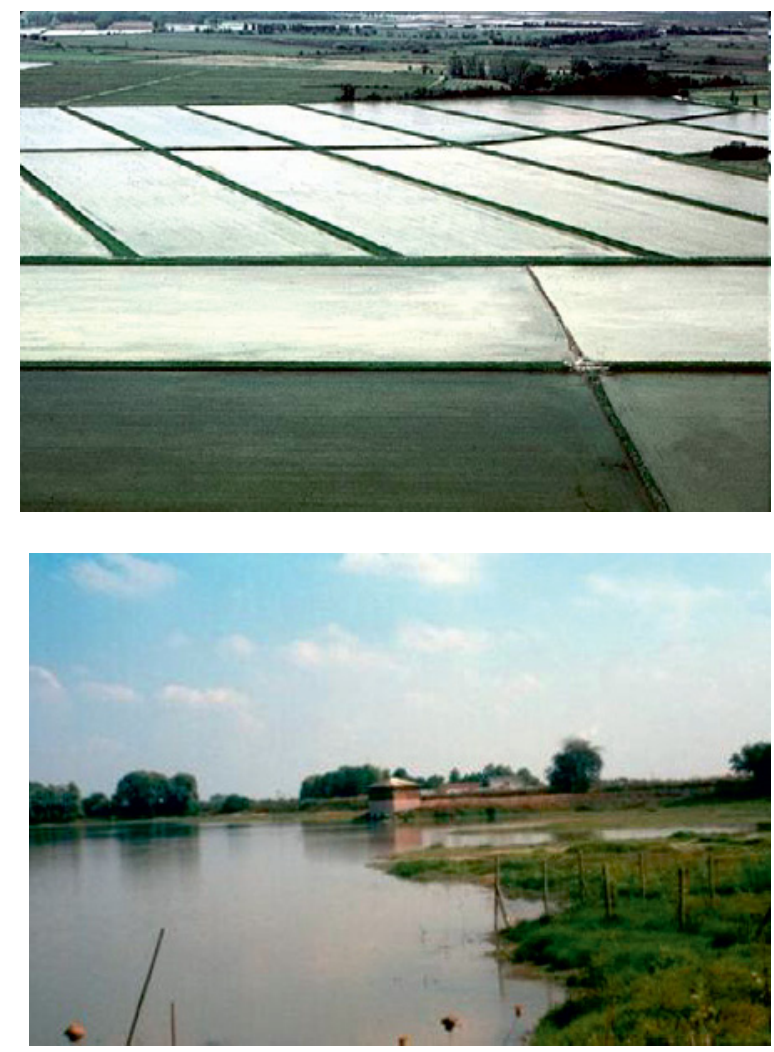

Figure 1. How to remedy to the negative environmental effects of the intensive agriculture: the transformation of a rice paddy into a WWF-Italy oasis to restore in the territory the wealth of animal and plant species which had been reduced by the introduction of intensive rice cultivation. 